\title{
THE CZECH CSR REPORTS: TOPICS AND QUALITY OF THEIR PROCESSING
}

\author{
[České CSR reporty: témata a kvalita jejich zpracování] \\ Klára Kašparová ${ }^{1}$ \\ ${ }^{1}$ Masarykova univerzita, Ekonomicko-správní fakulta, Lipová 41a, 60200 Brno \\ Email:klarad@econ.muni.cz
}

\begin{abstract}
From the long-term perspective, Europe as a whole has been described as the leader in reporting on socially responsible behaviour. European enterprises consider a compilation of CSR reports standard. Also, the quality of information provided is, compared to the surrounding regions, relatively high. However, several studies show that regional differences exist. In the Czech Republic, this type of reporting is still at the initial stage of development. Therefore, the first objective of the research is to find out whether Czech companies provide information about their social activities and what specific topics they prefer. The second objective is to determine what the quality of provided information is. To carry out this research, annual reports of 69 companies were assessed. The paper uses the method of conceptual content analysis. The results indicate that in their annual reports, companies tend to disclose issues beyond what is legally required. The most common reported topics concern the company's direction, information that promote the credibility of information provided and the confidence in the good corporate governance. However, the results also show that the quality of information provided is not too high.
\end{abstract}

Keywords: annual report, content analysis, corporate social responsibility reporting, quality, the Czech Republic.

JEL classification: M14

Doručeno redakci: 6.2.2018; Recenzováno: 20.2.2018; 5.3.2018; Schváleno k publikování: 13.6.2018

\section{Introduction}

Over a couple of decades, corporate social responsibility reporting has undergone significant development. At least in Europe, the activity originally performed by only a few corporations has become a common standard. According to the latest research of KPMG, 74\% European corporations report their social responsible behaviour (King et al. 2015). Quality of the reports issued by the European companies significantly beats the reports created in the rest of the world. This is largely influenced by activities of various organizations such as the European Commission, which introduced new regulation in this area valid from 2018.

Nevertheless, when taking a closer look it is obvious that the approach to CSR reports varies country to country - even among the leaders in CSR reporting in Europe (Branco et al. 2014). Majority of studies focuses on the CSR reporting in the developed Western countries where CSR reporting rate is 79\% (King et al. 2015). Research conducted within the Central and Eastern Europe is not so frequent - maybe due to a much lower CSR reporting rate (King et al. 2015). For this reason, this article focuses on the CSR reporting performed by the Czech companies.

The structure of the paper is as follows. The first section summarizes the current state of corporate social responsibility reporting in Europe. The second section presents the research objectives and describes the methodology used. The next section presents the empirical results and discussions and it is followed by a conclusion. 


\section{The current state of corporate social responsibility reporting}

The first information on corporate social responsibility reporting dates back to the seventies of the 20th century. CSR reports were then issued by corporations, whose activities were harmful to the environment. As a result, the reports were concentrating mainly on the environmental themes. Later, owing to the strengthening civil society, competition and increasing number of social and financial scandals, the demands put on the companies increased (Kašparová 2011, Bartels et al. 2016). As they needed to maintain their licenses to operate, the companies started to include other topics such as philanthropy, safety, and health at work in their reports. There are still more instruments that focus on environmental reporting than on social reporting but the number of the latter is currently growing faster (Bartels et al. 2016). With the development of CSR frameworks and instruments, the number of these themes increased even further. According to the WBCSD (2016), the stand-alone CSR report currently features 99 pages on average. For this reason, ways leading to shortening of such an unbearable number of pages while maintaining the core information are being sought. But on the other hand, findings of Lock and Seele (2016) show that the lengthier a CSR report the more credible it is.

At the end of 2014 the European Parliament and the Council adopted the Directive 2014/95/EU amending Directive 2013/34/EU as regards the disclosure of non-financial and diversity information by certain large undertakings and groups. The Directive requires publicinterest entities (these include for example listed companies, banks or insurance companies) with more than 500 employees to include a non-financial statement containing CSR information in their management report starting from 2018 (EU 2014). By this step, the European Union specifically demonstrated its efforts of CSR regulation which, until the release of a renewed EU strategy 2011-14 for Corporate Social Responsibility, had been perceived as a fully voluntary concept. This decision was probably caused by the finding that despite the fact European companies are the leaders in CSR reporting, fewer than $10 \%$ of them disclose CSR information regularly (Europa.eu 2013).

The Directive provides a definition of the CSR themes crucial for the EU region. These include the impact of the business activities on the environment, society and employees then respect for human rights, anti-corruption and bribery matters (EU 2014, p. 4). Further relevant themes can be derived from the instruments included in the Directive, where they are explicitly recommended to be followed. These involve EMAS, UN Global Compact, the OECD Guidelines for Multinational Enterprises, ISO 26000, the International Labour Organisation's Tripartite Declaration of principles concerning multinational enterprises and social policy and GRI's Sustainable Reporting Guidelines (EU 2014, p. 2).

The aim of the effort of the European Commission regarding obligatory topics included in CSR reports is to facilitate comparison of reports issued by individual corporations. This assumption is confirmed by issuing new guidelines (in June 2017) that should help companies in fulfilling their reporting obligations under current non-financial disclosure requirements and help them to increase consistency and comparability of their CSR reports (Europa.eu 2017). However, this is complicated by local preferences of selection of CSR themes (de Villiers and Marques 2015, Hąbek and Wolniak 2016).

For example, Swedish companies issue more information on their responsible business practices than Spanish companies (Branco et al. 2014). On the contrary, the Spanish companies more favour information on their community involvement than their Swedish counterparts (Branco et al. 2014). This way their reports largely resemble the reports of Polish 
corporations which, apart from community involvement, devote a lot of space also to the activities related to employees (Hąbek 2014). Compared with Anglo-Saxon business, the German companies provide more information on their responsibility to participate in the social and political processes at the national level (Chen and Bouvain 2009).

The regulation should thus increase CSR reporting and ensure disclosure on a regular basis. On the other hand, it could also limit opportunities for a company to distinguish itself through its CSR activities on the market and even reduce the quality of the reports by forcing it to tick the right boxes (Hąbek and Wolniak 2016). Currently, the European companies beat their counterparts from the other parts of the world in this point even though their average quality score is according KPMG only 68 out of possible 100 points (King et al. 2015).

The Member States had to transpose the Directive into their national laws by the end of 2016 (EU 2014, p. 8). It probably did not represent a major problem for western European corporations as many European countries had already included this requirement in their legislation independently of the Directive in advance - see e.g. UK, France, Netherlands, Norway, Sweden or Denmark (Hąbek 2014, Tschopp and Huefner 2015). The Czech Republic transposed the Directive into its Act on accounting at the end of the period. However, its requirements do not change much the volume of CSR reporting in the Czech Republic because it concerns probably only 5 companies (Czechia 2016). Nonetheless, there is a bigger modification. Since the latest change of the Act, only large companies with mandatory obligation to issue the annual report are obliged to include also information of non-financial character, which refers to the development of the company, its activities in the field of research and development, environmental protection and labour relations (Czechia 1991, section 21). There is a question if this change influences the volume of CSR reporting of small and medium companies in their annual reports.

The research presented in more details below focuses on the period before above-mentioned changes. It attempts to find out how selected companies approach CSR reporting, i.e. what CSR topics they prefer to inform of and what quality of presented information is, in the Czech Republic. The Czech Republic was chosen deliberately. There are not many studies concerning this topic here. The studies that focus on this topic often examine CSR reporting of the biggest companies or use the predefined coding scheme. This is not the case of this research. The research sample consists of CSR reports of all sizes of companies, and the coding scheme was created based on the first step of the grounded theory in order to reveal possible specific topics in the Czech CSR reports.

\section{Methodology}

Within this research, two research objectives were determined. The first one was to find out whether Czech companies provide information about their socially responsible activities and what specific topics they prefer in their CSR reports. To achieve this research objective, the content analysis method was selected. It enables to produce valid and trustworthy inferences based on analysis of written media (Horúcková and Bausassé 2017, p. 34). The coding scheme was adopted from author's previous research - see Kašparová 2011. It was created by means of open coding, in which the categories emerge themselves out of the text. This method allows for better depiction of specific features of the analysed document.

The content analysis was also used to achieve the second objective that was to determine what the quality of provided information is. The quality was measured by the scope of detail of provided information. The scope of detail was also created by means of open coding. The 
four-point scale was created based on this (for more see below). The higher rating the subtheme gained, the more detailed is the information, which is provided on it.

The are many channels that the company can use to inform its stakeholders of its CSR activities, e.g. its web site, social media profiles, stand-alone report or its annual report. The author selected the last mention option for several reasons. The main reason was that the results of the latest research show that including CSR themes in the annual report is now a firmly established global trend (King et al. 2015, Lock and Seele 2016) which is further strengthened by governments and regulators (Bartels et al. 2016). This trend is also relevant for the Czech Republic (Slater 2008, Petera, Wagner and Knorová 2016, Horúcková and Bausassé 2017). The results of previous studies also showed that the CSR reporting was not so widespread among small and medium companies that were included in the research sample. However, we can expect that at least certain CSR themes will be included in the annual reports regarding the given legislation. The advantage of the focus on the annual reports also lies in the fact that these are static documents, publicly available in the Czech Republic.

In total, 69 annual reports of the public limited companies from the processing industry (57 annual reports) and civil engineering (12 annual reports) for 2012 were analysed. 28 of them were from large companies, 27 from medium-sized companies and 14 from small companies. The number of annual reports and the selection of industry was determined by the linkage of this research to the previous work conducted by the author.

The author was a member of the team which examined the competitiveness of the Czech companies in 2007 (see Kašparová 2011). The study was focused only on two branches, e.g. on the processing industry and civil engineering, that are often considered to be the core branches of the Czech economy. That research sample consisted of 251 companies. The author selected only public limited companies from that research sample for the purpose to further examine their CSR reporting behaviour. The research sample was therefore reduced only to 125 companies. However, only 104 of them provided their annual reports covering relevant accounting period (the year 2006). In 2013, the author repeated the research. Nonetheless, only 69 of 104 companies provided their annual reports. The results of their analysis are presented below.

The analysis was carried out on the coherent text creating the core of the annual report only. The introductory pages and the annual accounts section were omitted. Each annual report was rated independently by two coders in order to increase the reliability of the research. Consequently, a comparison of their assessment results was conducted. In case of disagreeing ratings, the coders had to come to an agreement on the code. The data was processed in MS Excel and in SPSS.

\section{Results and discussion}

Within the research, two research objectives were determined. Their fulfilment will be elaborated in greater detail below.

\section{The choice of socially responsible themes}

In order to accomplish the first research objective, the author first researched what CSR themes companies report in their annual reports on. The adopted code scheme was very detailed. For this reason, the author merged the researched categories into higher units. Their occurrence is shown in Table 1. 
Table 1: Occurrence of CSR themes $(\mathrm{N}=69)$

\begin{tabular}{|l|l|l|}
\hline Themes & $\mathrm{N}$ & $\%$ \\
\hline Direction of the company & 54 & 78.3 \\
\hline Support of credibility of provided information & 51 & $77.3(\mathrm{~N}=66)$ \\
\hline Support of credibility of corporate management & 52 & 75.4 \\
\hline Support of feedback & 48 & 69.6 \\
\hline Efforts of environmental protection & 32 & 46.4 \\
\hline Obligations & 30 & 43.5 \\
\hline Cooperation with external stakeholders & 29 & 42.0 \\
\hline Support and protection of employees & 26 & 37.7 \\
\hline Compensation to the Statutory Body Members & 22 & 31.9 \\
\hline Community involvement & 8 & 11.6 \\
\hline
\end{tabular}

Source: Own processing.

The results show the often mentioned limitation of studying CSR reporting. It need not to reflect true social responsible activities of a company. According to the research by Skýpalová, Kučerová and Blašková (2016), Czech companies carry out activities in the areas of rejection of corruption, fraud and unfair competition, waste reduction and business ethics and corporate culture most often. In this research, only the information about protection of the environment was found under the creation of coding scheme in annual reports and just its occurrence was searched. As the results show, this theme is not among the most cited ones. This is not a good result because the Czechs expect two things from companies - protection of the environment and responsible behaviour toward their employees (Mackü 2016). Even the latest one does not belong to the most cited themes.

On the other hand, when comparing the themes communicated in the annual reports with the requirements of the Act 563/1991 on accounting relevant for the examined period it is obvious that the companies are not required to inform about their CSR only by the law. E.g. the mandatory information on environmental activities and labour relations are less frequently occurring in the annual reports than so-called voluntary information. This is e.g. information supporting credibility of provided information and trust in company management. Together with the information on direction of the company, these themes belong among the most frequently mentioned ones.

More specifically, the results show that the direction of the company is the most frequently mentioned CSR theme in the annual reports. This information can be found in $78.3 \%$ annual reports. In more than half of the cases $(53.6 \%)$, this information is provided in the form of formulation of priorities, targets or efforts for current or future period. The areas in which they are defined differ, though. In the current period, these are most frequently priorities, targets of efforts of the company relating to production or to a product ( 23 annual reports), environment or financial area (both in 17 annual reports). In the future period, the priorities, targets or efforts cover the financial area (30) and production or products (20). Nevertheless, only 9 corporations inform of the way how to achieve them.

The second most frequently represented category $(77.3 \%)$ is the information enhancing credibility of the text of the annual report. The credibility was measured by an occurrence of Proclamation of the Board of Directors or the Supervisory Board or their members on quality of data stated in the annual report and by an occurrence of assurance of alignment of the annual reports with annual accounts from the auditor. The first is contained in just 14 annual reports, the second in 46 annual reports. Although the assurance is on a limited level in all 
cases, the Czech companies do not differ from their world's counterparts as findings made by World Business Council for Sustainable Development (2016) confirm.

The results show that the Czech companies involve the voluntary third-party verification of their annual reports in much greater extent than usual in the world's biggest companies and the largest 100 national companies searched in 45 countries by KPMG (67\% versus 63\%, resp. $42 \%$ - see King et al. 2015). In any case, the rate of this type of assurance is even going to increase because the amendment of Act on Auditors imposes duty on auditors to report on the fact, that information included in the annual reports does not contain significant misstatements of fact based on their findings learned from mandatory audit since 2016 (Deloitte 2017). However, then it will be not possible to call it voluntary verification. In this context, Wong and Millington (2014) point out that the assurance may help increase credibility of the text, but only if stakeholders rely on assurance statements. Their findings show that stakeholders have more confidence in assurance provided by consultants who are not financial auditors in spite of the fact that the most volume of assurance statement is provided by Big 4 (Wong and Millington 2014).

The third most frequently communicated category $(75.4 \%)$ is the information supporting credibility of the corporate management. It was measured by occurrence of information about norms, non-financial audit, control, lawsuits and rationalisation and optimisation of processes. Most typically the information is limited just to certification according to a selected standard (34 annual reports) and information on carried out audits (32 annual reports). The nonfinancial audits were most often linked to ISO standards.

At the first look it may seem that the Czech companies are focused very strongly on gaining the feedback because the category occurring in more than half of the annual reports $(69.6 \%)$ is the information supporting the feedback. Unfortunately, annual reports rarely contain information on the specific person responsible for creation of the annual report. This information is given by only 12 companies and in majority of cases (8) the names are given without a specific contact to these persons. So, it cannot be regarded as proactive supporting of feedback. However, the Czech companies do not differ in this from their European counterpart as Hąbek and Wolniak's findings show (2016). Dvořáková, Krasnikova and Quigley's findings (2015) also point out that the absence of contact persons is not solely problem of the text of the annual reports but also CSR presentation on web pages.

Efforts of environmental protection are most frequently demonstrated through communication of information on corporate activities in this area (30 annual reports). Only two annual reports mentioned savings or benefits arising from the efforts of environmental protection. In case the company mentions some obligations, they mostly concern (25) the financial area. When referring to cooperation or in more general terms to relations, the most frequently mentioned are the business partners (13) and educational institutions (8). In case the companies inform on relationships with employees, most frequently they mention the issue of their development (21) than the benefits provided (15) or work safety measures (13). Petera, Wagner and Boučková (2014) come to the same result in their research.

The information on community involvement is the least frequent. This can be regarded surprising. The historical development of the CSR reporting (Kašparová 2011) together with studies conducted in countries where, similar to the Czech Republic, CSR reporting is just at its beginning (Bashtovaya 2014, Hąbek 2014) show that the community involvement is the major theme of CSR reports. 


\section{The quality of information provided}

To fulfil the second objective the author researched to what detail the companies inform on the individual CSR themes in their annual reports. During the creation of the coding scheme, the author found out that the scope of detail of the provided information can be researched only with selected themes. For this reason, only these themes entered the analysis exploring the rate of detail of the provided information. The four-point scale was created again by means of the open coding. 0 means that the theme was not mentioned. Point 1 means that the theme was mentioned, but very generally without providing any examples of activities. Point 2 means that the description of the theme was detailed with providing the examples of activities however without any numbers. Point 3 means that the text contains examples of activities and the numbers (e.g. costs, evolution during the time etc.) Attribute "--." expresses the fact that the higher degree of detail was not detected during the open coding and thus it was not launched within the coding scheme - for more information see Kašparová 2011. This consequent research took over the scheme and only themes and sub-themes listed within were evaluated. The detailed results are summarized in Table 2.

Table 2: Rate of detail of selected information

\begin{tabular}{|c|c|c|c|c|}
\hline \multirow[b]{2}{*}{ Themes /sub-themes } & \multirow[b]{2}{*}{$\mathrm{N}$} & \multicolumn{3}{|c|}{ Rate of detail } \\
\hline & & 1 & 2 & 3 \\
\hline \multicolumn{5}{|c|}{ Support of credibility of corporate management } \\
\hline Selected norms & 34 & 38.2 & 35.3 & 26.5 \\
\hline Non-financial audit & 12 & 41.7 & 50.0 & 8.3 \\
\hline Control & 32 & 25.0 & 68.8 & 6.3 \\
\hline Lawsuits & 7 & 100.0 & 0.0 & --- \\
\hline \multicolumn{5}{|l|}{ Efforts of environmental protection } \\
\hline Investment - environment & 4 & 75.0 & 25.0 & 0.0 \\
\hline Activities - environment & 30 & 56.7 & 43.3 & --- \\
\hline Savings / earnings & 2 & 50.0 & 50.0 & 0.0 \\
\hline Cooperation with external stakeholders & 29 & 41.4 & 58.6 & --- \\
\hline \multicolumn{5}{|l|}{ Support and protection of employees } \\
\hline Employee development & 21 & 71.4 & 28.6 & --- \\
\hline Provision of benefits & 15 & 6.7 & 46.7 & 46.7 \\
\hline Safety and health protection & 13 & 100.0 & 0.0 & --- \\
\hline
\end{tabular}

Source: Own processing.

Regarding the low number of annual reports informing on certain themes it is necessary to take a cautious approach to the conclusions. The research results reveal that only a negligible part of the companies provides truly detailed information including the quantitative expression (point 3). So we can conclude that the quality of provided information is low and in the majority of cases, the information is communicated only in a general, narrative form. Petera, Wagner and Boučková (2014) or Horúcková and Bausassé (2017) come to the same result in their research carried out in the Czech Republic.

The only exception is the information on employees' benefits. In the majority of cases, the themes are mentioned excluding the additional data. Only when informing on the audits performed and cooperation with external stakeholders, the companies provide more information. This finding is also confirmed by Petera, Wagner and Boučková's research results (2014). 


\section{Conclusion}

The form of CSR reporting has changed significantly throughout the past several decades. Currently, the production of CSR reports represents a standard - at least in the developed European countries. This status was predeceased by the quite hectic development of various standards and associations, which, together with cultural differences within the individual countries and differently developed civil society, caused that the contents of the CSR reports differ significantly country to country. This fact makes a comparison of individual reports difficult. This is obviously one of the reasons why the European Union decided to impose at least a partial regulation of CSR reporting and enhance thus advantages that can be brought by the publishing of the CSR reports.

The research presented above was focused on the period before the implementation of the Directive into the Act on accounting in the Czech Republic. Its first research objective was to determine whether selected Czech companies from two branches provide information about their socially responsible activities and what specific topics companies prefer in their CSR reports. The results show that the Czech companies are not driven to publish the CSR information solely by their statutory duties. It means that they will probably continue to publish these pieces of information in their annual reports even under the new regulation where only the large companies have this duty. The most frequently the companies publish information on the direction of the company, which can be perceived as their statutory duty, together with information supporting the credibility of the provided information and trust in the corporate management, whose publication is not conditioned by any legislative measure. Nonetheless, the Directive does not see these topics as crucial ones for EU region.

The second research objective was to find the quality of provided information on socially responsible activities within the CSR reports of the Czech companies. The research reveals that the quality of information provided is low as the information contained in the annual reports is very general and narrative. Several other studies come to the same result - not only in the Czech Republic. The only exception is the information on employees' benefits. It would be interesting to find out what causes it. There are many possible explications. The company is used to assemble the information in this detail for other purposes, so its release in this scope of detail does not increase the cost to create an annual report. The company could also use the annual report as one of the possible channels to attract potential candidates and to show them this way its generosity.

However, it would be good to mention that the research has several limitations. The first of these is due to the choice of objectives, method and materials for the analysis. It focuses only on researching CSR disclosure and does not correspond to the company's actual conduct. Further research, however, could connect these areas and discover whether there exists a disparity between the information provided and the actual conduct. There are also many possibilities where the company can publish information about its CSR activities. The author selected annual reports for several reasons. However, every channel influences the content. Further research could thus connect these channels and discover differences in content. The last limitation lies in the sample size.

\section{References}

[1] BARTELS, W., T. FOGELBERG, A. HOBALLAH and C. T. VAN DER LUGT, 2016. Carrots Sticks. Global trends in sustainability reporting. Regulation and policy. [Online]. [Accessed: 2017, November 30]. Available from: https://www.carrotsandsticks.net/wpcontent/uploads/2016/05/Carrots-Sticks-2016.pdf. 
[2] BASHTOVAYA, V., 2014. CSR reporting in the United States and Russia. Social Responsibility Journal. 10(1): 68-84. ISSN: 1747-1117.

[3] BRANCO, M., C. DELGADO, M. SÁ and C. SOUSA, 2014. Comparing CSR communication on corporate web sites in Sweden and Spain. Baltic Journal of Management. 9(2): 231-250. ISSN: 1746-5265.

[4] CHEN, S. and P. BOUVAIN, 2009. Is Corporate Responsibility Converging? A Comparison of Corporate Responsibility Reporting in the USA, UK, Australia, and Germany. Journal of Business Ethics. 84: 299-317. ISSN: 1573-0697.

[5] CZECHIA, 1991. Act 563/1991 of 12 December 1991 on accounting [in Czech: Zákon 563/1991 ze dne 12. prosince 1991 o účetnictví]. In: Collection of Law 107/2802-2810. 61 p. Available from: http://www.mfcr.cz/cs/verejny-sektor/ucetnictvi-a-ucetnictvistatu/ucetni-reforma-verejnych-financi-ucetnic/pravni-predpisy/platna-legislativazakony/2016/zakony-pro-rok-2016-pro-ucetnictvi-statu-25444.

[6] CZECHIA, 2006. Act 262/2006 of 21 April 2006, Labour Code [in Czech: Zákon 262/2006 ze dne 21. dubna 2006, Zákoník práce]. In: Collection of Law 84/3146-3241. 235 p. Available from: https://portal.gov.cz/app/zakony/zakon.jsp?page=0\&nr=262 2F2006\&rpp=15\#seznam.

[7] CZECHIA, 2016. Government bill Act of 27 April that change Act No. 563/1991 on Accounting [in Czech: Vládní návrh ZÁKON ze dne 27. dubna 2016, kterým se mění zákon č. 563/1991 Sb., o účetnictví]. 19 p. Available from: https://www.psp.cz/sqw/text/orig2.sqw?idd=126641.

[8] DELOITTE, 2017. Accounting News: Deloitte the Czech Republic [in Czech: Účetní novinky: Deloitte Česká republika]. [Online]. [Accessed 2017, November 25]. 17 p. Available from: https://edu.deloitte.cz/cs/Content/Download/accounting-news-1702.

[9] DE VILLIERS, C. and A. MARQUES, 2015. Corporate social responsibility, countrylevel predispositions, and the consequences of choosing a level of disclosure. Accounting and Business Research. 46(2): 167-195. ISSN: 2159-4260.

[10] DVOŘÁKOVÁ, Z., D. KRASNIKOVA and M. D. J. QUIGLEY, 2015. Non-financial reporting: The case of the Czech Republic. In: The 9th International Days of Statistics and Economics. [Online]. [Accessed: 2017, December 28]. Slaný: Libuše Macáková, MELANDRIUM, $\quad$ 381-390. Available from: https://msed.vse.cz/msed_2015/article/17-Dvorakova-Zuzana-paper.pdf

[11] EU, 2014. Directive 2014/95/EU of the European Parliament and of the Council of 22 October 2014 amending Directive 2013/34/EU as regards disclosure of non-financial and diversity information by certain large undertakings and groups [in Czech: Směrnice Evropského parlamentu a Rady 2014/95/EU ze dne 22. ř́jna 2014, kterou se mění směrnice 2013/34/EU, pokud jde o uvádění nefinančních informací a informací týkajících se rozmanitosti některými velkými podniky a skupinami]. In: Official Journal of the European Union. OJ L330/1-9. [Online]. [Accessed: 2017, November 28]. 9 p. Available from: http://eur-lex.europa.eu/legalcontent/CS/TXT/PDF/?uri=CELEX:32014L0095\&from=CS.

[12] Europa.eu, 2013. European Commission - Press release - Commission moves to enhance business transparency on social and environmental matters. [Online]. [Accessed: 2017, November 28]. Available from: http://europa.eu/rapid/press-release_IP-13-330_en.htm. 
[13] Europa.eu, 2017. European Commission - Press release - Commission takes further steps to enhance business transparency on social and environmental matters. [Online]. [Accessed: 2017, November 28]. Available from: http://europa.eu/rapid/press-release_IP17-1702_en.htm.

[14] HĄBEK, P., 2014. Evaluation of sustainability reporting practices in Poland. Quality \& Quantity. 48: 1739-1752. ISSN: 1573-7845.

[15] HĄBEK, P. and R. WOLNIAK, 2016. Assessing the quality of corporate social responsibility reports: the case of reporting practices in selected European Union member states. Quality \& Quantity. 50: 399-420. ISSN: 1573-7845.

[16] HORÚCKOVÁ, M. and T. BAUDASSÉ, 2017. Content analysis applied to social and environmental reporting. Acta academica karviniensia. XVII(4): 32-45. ISSN: 25337610 .

[17] KAŠPAROVÁ, K., 2011. Corporate Social Responsible Reporting [in Czech: Reportování o společenské odpovědnosti podniku]. 1st edition. Brno: Masaryk University.

[18] KING, A., W. BARTELS, M. MCKENZIE and E. AUSTIN, 2015. Currents of change. The KPMG Survey of Corporate Responsibility Reporting 2015. [Online]. [Accessed: 2017, December 15]. Netherlands: Haymarket Network. Available from: https://home.kpmg.com/content/dam/kpmg/pdf/2015/12/KPMG-survey-of-CR-reporting2015.pdf.

[19] LOCK, I. and P. SEELE, 2016. The credibility of CSR (corporate social responsibility) reports in Europe. Evidence form a quantitative content analysis in 11 countries. Journal of Cleaner Production. 122: 186-200. ISSN: 0959-6526.

[20] MACKUं, T., 2016. CSR and reputation are going hand in hand: Ipsos CSR Research confirms [in Czech: CSR a reputace jdou ruku v ruce - potvrzuje Ipsos CSR Research]. [Online]. [Accessed: 2017, November 25]. Ipsos.cz. Available from: http://www.ipsos.cz/csr-a-reputace-jdou-ruku-v-ruce-potvrzuje-ipsos-csr-research/.

[21] PETERA, P., J. WAGNER and M. BOUČKOVÁ, 2014. Analysis of CSR Reporting Practices of the Largest Companies Domiciled in the Czech Republic. In: The International Scientific Conference INPROFORUM. [Online]. [Accessed: 2017, December 11]. České Budějovice: University of South Bohemia in České Budějovice, Faculty of Economics, pp. 21-27. Available from: http://ocs.ef.jcu.cz/index.php/inproforum/INP2014/paper/viewFile/618/438.

[22] PETERA, P., J. WAGNER and K. KNOROVÁ, 2016. Perception and interpretation of sustainability among the largest corporations established in the Czech Republic. Acta Universitatis Agriculturae et Silviculturae Mendelianae Brunensis. 64(3): 1053-1065. ISSN 2464-8310.

[23] SKÝPALOVÁ, R., R. KUČEROVÁ and V. BLAŠKOVÁ, 2016. Development of the Corporate Social Responsibility Concept in Small and Medium-Sized Enterprises. Prague Economic Papers. 25(3): 287-303. ISSN 2336-730X.

[24] SLATER, A., 2008. KPMG International Survey of Corporate Responsibility Reporting 2008. [Online]. [Accessed: 2015, September 25]. Amsterdam: KPMG Sustainability. Available from: https://www.kpmg.com/EU/en/Documents/KPMG_International_survey_Corporate_resp onsibility_Survey_Reporting_2008.pdf. 
[25] TSCHOPP, D. and R. HUEFNER, 2015. Comparing the Evolution of CSR Reporting to that of Financial Reporting. Journal of Business Ethics. 127: 565-577. ISSN: 1573-0697.

[26] WBCSD, 2016. Reporting Matters. Communicating on the Sustainable Development Goals. [Online]. [Accessed: 2017, September 25]. Geneva: World Business Council for Sustainable Development. Available from: http://www.wbcsd.org/Projects/Reporting/Resources/Reporting-Matters-2016.

[27] WONG, R. and A. MILLINGTON, 2014. Corporate social disclosures: a user perspective on assurance. Accounting, Auditing \& Accountability Journal. 27(5): 863887. ISSN: 0951-3574. 